\title{
PELAYANAN TRAUMA HEALING BAGI KORBAN GEMPA LOMBOK
}

\author{
Wiwit Puspitasari Dewi ${ }^{1}$, Krishervina R. Lidiawati², Pradipta C. Pratiwi ${ }^{3}$ \\ ${ }^{1,2,3}$ Universitas Pelita Harapan, Kawaraci \\ wiwit.dewi@uph.edu,krishervina.lidiawati@uph.edu, \\ pradipta.pratiwi@gmail.com
}

\begin{abstract}
Abstrak
Rangkaian bencana gempa bumi Lombok sejak 29 Juli 2018 yang dilanjutkan dengan ratusan gempa susulan menimbulkan dampak fisik maupun psikologis bagi para korbannya, salah satunya adalah munculnya gejala trauma. Gejala trauma membuat korban mengalami disfungsi serta hambatan dalam menjalani rutinitas seharihari sehingga diperlukan adanya kegiatan yang bertujuan untuk memberikan informasi dan mengajarkan keterampilan guna menjadi lebih stabil dan dapat kembali beradaptasi dengan kehidupan mereka. Kegiatan yang dilaksanakan disebut Trauma Healing yang merupakan lanjutan dari kegiatan serupa yang sudah terlebih dahulu dilakukan. Tim dosen Fakultas Psikologi UPH dengan latar belakang pendidikan psikologi klinis dan pendidikan bermitra dengan Baptist Global Response International (BGRI) melaksanakan kegiatan yang berbentuk seminar dan workshop selama satu hari di Lombok pada 27 Oktober 2018. Sebanyak 23 peserta yang merupakan korban gempa sekaligus relawan beberapa komunitas di Lombok mengikuti kegiatan yang terbagi atas tiga bagian. Bagian pertama adalah seminar mengenai trauma dan Psychological First Aid (PFA), bagian kedua adalah seminar dan workshop mendengarkan aktif, dan bagian ketiga adalah workshop teknik ekspresi emosi dan relaksasi. Hasilnya kegiatan ini merupakan kegiatan yang baik dan peserta mendapatkan pengetahuan yang baru mengenai trauma, Psychological First Aid (PFA), teknik mendengar aktif, serta teknik-teknik yang membantu korban trauma dalam mengekspresikan emosi dan relaksasi.
\end{abstract}

Kata Kunci : trauma healing, seminar, workshop, bencana, gempa bumi, Lombok

\section{PENDAHULUAN}

Kondisi geografis Indonesia yang berada di antara beberapa lempengan bumi dan menjadi bagian dari gugusan gunung berapi di dunia menyebabkan negara kita rentan mengalami gempa bumi vulkanik maupun tektonik. Salah satu daerah yang mengalami gempa bumi yang cukup parah adalah Lombok. Gempa bumi yang terjadi di Lombok dimulai pada 29 Juli 2018 dan diikuti dengan ratusan gempa susulan yang dirasakan di semua bagian Pulau Lombok (BMKG, 2018). Gempa awal yang berkekuatan 6.4 SR tersebut mengakibatkan 1000 rumah rusak dan 5000 warga mengungsi di tenda-tenda pengungsian (BBC, 2018). Namun banyaknya gempa susulan mengakibatkan bertambahnya jumlah korban jiwa, kerusakan, dan juga kerugian baik secara materiil maupun non material. Badan Nasional Penanggulangan Bencana (BNPB, 2018) mencatat, pada awal Agustus 2018 sudah terdapat korban jiwa sebanyak 436 orang, dengan korban luka-luka sejumlah 1353 orang, dan 352.793 orang harus mengungsi dari tempat tinggalnya. Angka ini terus bertambah sehingga pada bulan Oktober 2018 diketahui jumlah korban meningkat menjadi 564 korban jiwa dengan korban luka-luka sebanyak 1.584 orang (Lestari, 2018). Sebagai bagian dari

$$
\text { Lingkungan Hidup dan Bencana }
$$


program penanggulangan bencana, BNPB terus melakukan pembangunan kembali bangunan fisik yang rusak. Namun bagi individu yang menjadi korban, BNPB juga melakukan upaya penanganan untuk membantu mereka melalui kegiatan trauma healing dan Pychological First Aid (PFA) (BNPB, 2018).

Trauma dapat didefinisikan sebagai respon terhadap suatu peristiwa yang merusak hidup yang aman sehingga tidak lagi dipandang sebagai tempat perlindungan (Wright, 2011). Kecelakaan, perkosaan, atau bencana alam merupakan beberapa contoh kejadian buruk yang bisa menyebabkan terjadinya kondisi trauma pada seseorang (APA, 2019). Trauma dipandang sebagai suatu hal yang lebih dari suatu kondisi krisis, tetapi merupakan suatu reaksi yang normal terhadap peristiwa abnormal yang melebihi kemampuan seseorang untuk beradaptasi dalam hidup sehingga individu tersebut merasa tidak berdaya (Wright, 2011). Saat seseorang mengalami kejadian bencana, maka respon umum yang dapat terjadi adalah perubahan perasaan yang tidak terduga, perubahan dalam pemikiran dan perilaku, lebih sensitif terhadap perubahan lingkungan, kesulitan dalam interaksi sosial, mengalami masalah terkait dengan kondisi fisik mereka (APA, 2013). Dalam kondisi yang lebih berat, beberapa bentuk gangguan psikologis yang dapat dialami individu yang mengalami trauma adalah Post-Traumatic Stress Disorder (PTSD) atau Acute Stress Disorder.

Menurut Diagnostic and Statistical Manual of Mental Disorders Edisi ke-5 (DSM-5), terdapat beberapa gejala utama yang dialami oleh individu dengan PTSD yaitu intrusion (munculnya ingatan yang berulang dan juga tidak menyenangkan mengenai kejadian yang menyebabkan trauma, misalnya melalui mimpi atau flashback), avoidance (menghindari segala sesuatu yang terkait atau mengingatkan kejadian traumatis), serta perubahan dalam reaktivitas (Misalnya: mudah marah, gampang terkejut, sulit tidur, hypervigilance, sulit berkonsentrasi) (American Psychiatric Association, 2013). Gejala-gejala tersebut juga dialami para korban gempa di Lombok. Laporan dari Wirahadi \& Wahyuningsih (2018) menyatakan terdapat korban yang dirawat di RSUD Nusa Tenggara Barat (NTB) yang sensitif dengan suara keras, merasakan adanya goyangan walaupun sebenarnya tidak ada gempa yang terjadi. Tambahan informasi juga didapatkan dari Kasubbaghumas RSUD NTB, bapak Solikin, di mana menurutnya terdapat beberapa korban yang terlihat menghindari bangunan dan tidak mau masuk ke tenda. Munculnya berbagai gejala trauma ini menyebabkan diperlukannya pelayanan trauma healing bagi para korban gempa bumi di Lombok.

Dengan adanya kebutuhan yang mendesak akan layanan trauma healing, serta mengingat banyaknya korban yang membutuhkan bantuan dengan segara, maka dibutuhkan relawan-relawan yang sudah mendapatkan pelatihan dan dapat melakukan pendampingan pada masyarakat untuk mengatasi trauma yang mereka alami. Namun menurut Joshua Tan, direktur dari Baptist Global Response International, jumlah relawan di Lombok yang terlatih dalam penanganan bencana dirasakan masih kurang. Para pemimpin komunitas lokal juga tidak memiliki bekal yang dapat digunakan untuk menenangkan warga binaannya (Komunikasi Personal, Agustus 2018). Melihat permasalahan tersebut, pihak Baptist Global Response International berinisiatif untuk melakukan training yang membekali para relawan serta para pemimpin komunitas lokal untuk menangani korban trauma dengan cepat. Kegiatan Trauma Healing yang pertama kali dilakukan oleh BGRI pada bulan September 2018. Namun berdasarkan evaluasi dari kegiatan tersebut, disimpulkan bahwa masih terdapat kebutuhan akan adanya program trauma healing di Lombok mengingat masih ada para relawan dan pemimpin komunitas yang belum mengikuti kegiatan di bulan September 2018 (Komunikasi Personal, Oktober 2018). Untuk menjawab permasalahan tersebut, maka kegiatan Trauma Healing perlu kembali dilakukan di Lombok.

Adapun mitra institusi untuk kegiatan Pengabdian kepada Masyarakat (PkM) ini adalah Baptist Global Response International (BGRI). BGRI merupakan sebuah badan amal yang terdaftar di Singapura dan merupakan lembaga swadaya masyarakat yang bekerja untuk memenuhi kebutuhan penduduk dunia. BGRI telah berpengalaman dalam pelayanan berupa pemberian konsultasi, manajemen dan kemitraan proyek, Lingkungan Hidup dan Bencana

611 
pelatihan untuk meresponi bencana, pengembangan komunitas, pelatihan SPHERE Project, dan pelatihan untuk corporate responsibility awareness. Kegiatan Trauma Healing ini sendiri merupakan perpanjangan dari salah program yang dilakukan BGRI dalam penanggulangan bencana di Lombok, yaitu terkait dengan pelatihan konseling trauma.

\section{Kegiatan Trauma Healing yang} dilaksanakan merupakan kegiatan yang bertujuan untuk memberikan pelatihan dasar sebagai salah satu langkah pemulihan korban dengan target peserta yaitu masyarakat lokal yang menjadi mitra kerja BGRI di Lombok. Mengingat gempa bumi susulan yang masih terjadi, maka respon-respon trauma masih banyak terjadi pada masyarakat di Lombok. Diperlukan adanya langkah awal untuk mendukung para korban gempa dengan segera melalui edukasi mengenai Psychological First Aid (PFA). Pemberian PFA dengan segera pada korban bencana dapat membantu mereka menjadi lebih baik dalam jangka waktu yang panjang karena adanya perasaan aman dan terhubung dengan orang lain, memiliki akses dukungan sosial dan fisik, serta meningkatkan adanya sense of control melalui kemampuan menolong diri sendiri (WHO, 2016). Selain itu, munculnya gejala-gejala PTSD pada para korban membuat diperlukannya pelatihan mengenai teknik-teknik praktis untuk membantu mengatasi gejala tersebut.

Materi yang akan digunakan dalam kegiatan kali ini mencakup materi dasar mengenai trauma, PFA, cara berkomunikasi melalui mendengar, serta teknik-teknik ekspresi emosi dan relaksasi. Materi ini diadaptasi dari materi Ibu Jessica Ariela yang merupakan konselor pelatihan sebelumnya, namun dengan penyesuaian dalam pemilihan kegiatan yang dilakukan. Melalui kegiatan Trauma Healing ini, diharapkan para mitra kerja yang berada di Lombok dapat berfungsi lebih baik dalam kehidupan seharihari serta mengaplikasikan pengetahuan yang didapatkan kepada komunitas yang ia layani. Dengan begitu, diharapkan gejala trauma yang dialami oleh masyarakat dapat berkurang dan hal ini dapat membantu masyarakat Lombok untuk pulih secara psikologis dari kondisi trauma yang dialami akibat bencana gempa bumi.

\section{METODE}

Kegiatan Trauma Healing kedua ini dilakukan karena adanya kebutuhan berupa pemberian informasi mengenai trauma serta caracara mengatasi korban dengan trauma untuk masyarakat umum di Lombok serta orang-orang dalam komunitas yang akan berinteraksi dengan para korban. Bentuk kegiatan berupa seminar dan worksop yang dilakukan selama satu hari di Sekolah Tinggi Teologia (STT) Baptis Lombok. Kegiatan ini berlangsung pada hari Sabtu, 27 Oktober 2018 dan diikuti oleh 23 peserta dari berbagai kalangan yaitu penduduk setempat (Lombok), mahasiswa, relawan dari luar daerah Lombok. Partisipan merupakan orang-orang yang nantinya akan turun langsung dalam memberikan pelayanan bagi para korban.

Terdapat tiga sesi kegiatan yang difasilitasi oleh masing-masing anggota tim pengabdian masyarakat yang merupakan para dosen Fakultas Psikologi Universitas Pelita Harapan sekaligus psikolog dengan latar belakang pendidikan psikologi klinis dan juga pendidikan. Pada sesi pertama dilakukan pemberian psikoedukasi melalui seminar mengenai "Trauma dan penanganan Psychological First Aid (PFA)". Sesi kedua merupakan sesi seminar dan workshop mengenai "Mendengarkan Aktif". Sesi terakhir merupakan workshop mengenai "Teknik Ekspresi Emosi dan Relaksasi". Pada akhir dari setiap sesi dilakukan kegiatan tanya jawab antara pemberi materi dan peserta. Setelah semua kegiatan selesai, peserta menuliskan evaluasi kegiatan.

\section{HASIL DAN PEMBAHASAN}

\section{Hasil Kegiatan}

Secara umum peserta terlihat antusias dalam mengikuti kegiatan trauma healing ini. Hal ini ditunjukkan dari kedatangan mereka yang lebih awal dari waktu yang telah ditentukan, keterlibatan yang cukup aktif selama kegiatan, dan banyaknya pertanyaan yang diajukan. Adapun kegiatan trauma healing ini terbagi menjadi tiga sesi dengan tiga pembicara yang berbeda. Sesi pertama yaitu materi pemahaman tentang trauma dan Psychological First Aid (PFA) dibawakan oleh Ibu Wiwit Puspitasari Dewi. Sesi kedua yaitu materi mendengarkan dan 
relaksasi dibawakan oleh ibu Pradipta Christy. Kemudian sesi terakhir yaitu materi tehnik bermain dan bercerita dibawakan oleh Ibu Krishervina Rani Lidiawati.

Tabel 1. (Detil Kegiatan Trauma Healing)

\begin{tabular}{clr}
\hline Sesi & \multicolumn{1}{c}{ Kegiatan } \\
\hline \multirow{2}{*}{ Pertama } & $\begin{array}{l}\text { Edukasi mengenai definisi trauma, } \\
\text { gejala-gejala Gangguan Stres }\end{array}$ \\
(Trauma dan PFA) & $\begin{array}{l}\text { Pascatrauma, Psychological First } \\
\text { Kedua }\end{array}$ & $\begin{array}{l}\text { Aid (PFA). } \\
\text { Edukasi tentang perbedaan }\end{array}$ \\
mendengar dan mendengarkan, \\
(Mendengar Aktif) & proses mendengarkan, workshop \\
& untuk latihan mendengarkan \\
Ketiga & (dilakukan berpasangan). \\
Edukasi dan pelatihan mengenai \\
teknik Ekspresi & teknik ekspresi emosi, seperti \\
kmosi dan & kegiatan menggambar, bercerita \\
Relaksasi) & menggunakan boneka jari. Edukasi \\
& dan pelatihan mengenai teknik \\
& relaksasi melalui latihan \\
& pernapasan, butterfly hug, dan \\
& meniup busa sabun. \\
\hline
\end{tabular}

Pada sesi pertama, peserta diberikan informasi mengenai definisi trauma serta gejalagejala yang ditampilkan oleh seseorang setelah menghadapi peristiwa traumatis. Gejala ini tampil melalui perilaku, pemikiran yang dimiliki, serta perasaan/emosi yang dialami. Mengingat para peserta sudah turun ke lapangan sebelumnya untuk menemui para korban, maka dilakukan juga diskusi mengenai gejala-gejala yang ditemukan oleh peserta sesuai konteks korban gempa bumi di Lombok. Informasi selanjutnya yang diberikan kepada peserta adalah mengenai hal-hal yang bisa dilakukan sebagai pendampingan pertama pada korban bencana alam, melalui penjelasan mengenai Psychological First Aid (PFA). Secara umum peserta diberikan informasi mengenai prinsip dasar PFA, yaitu mengenai Look, Listen, dan Link yang diambil dan diadaptasi dari materi edukasi WHO (2016). Diskusi kembali dilakukan untuk menyesuaikan dengan pengalaman para peserta saat menemui para korban.

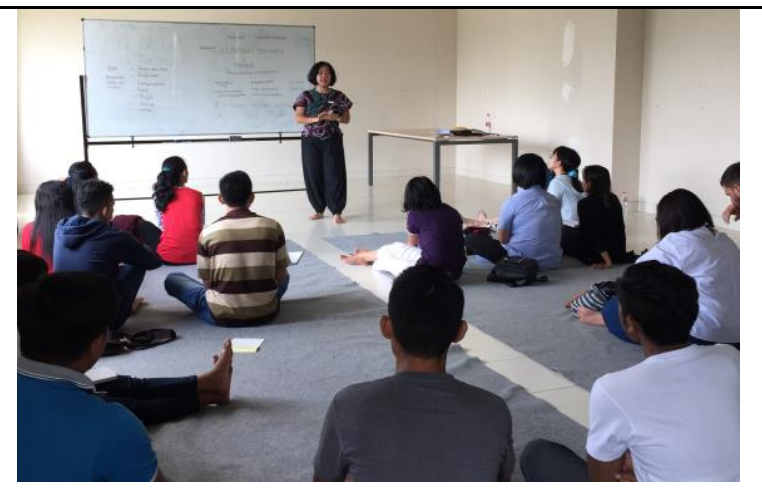

Gambar 1. Pelaksanaan Seminar mengenai Gejalagejala Trauma

Sesi kedua dimulai dengan diskusi mengenai perbedaan antara "Mendengar dan Mendengarkan". Peserta juga diberikan informasi mengenai beberapa teknik mendengar aktif seperti bagaimana cara memberikan penguatan, menunjukkan penerimaan, merefleksikan perasaan, menyampaikan hasil observasi, serta melakukan probing melalui pemberian pertanyaan terbuka. Setelah kegiatan edukasi diberikan, maka pembawa materi melakukan simulasi bersama salah seorang peserta untuk memberikan pemahaman kepada peserta dalam membedakan teknik mendengar yang baik dan buruk bersama. Sesi kedua ini diakhiri dengan simulasi mendengar aktif yang dilakukan oleh seluruh peserta secara berpasangan serta sharing pengalaman saat simulasi oleh beberapa peserta.

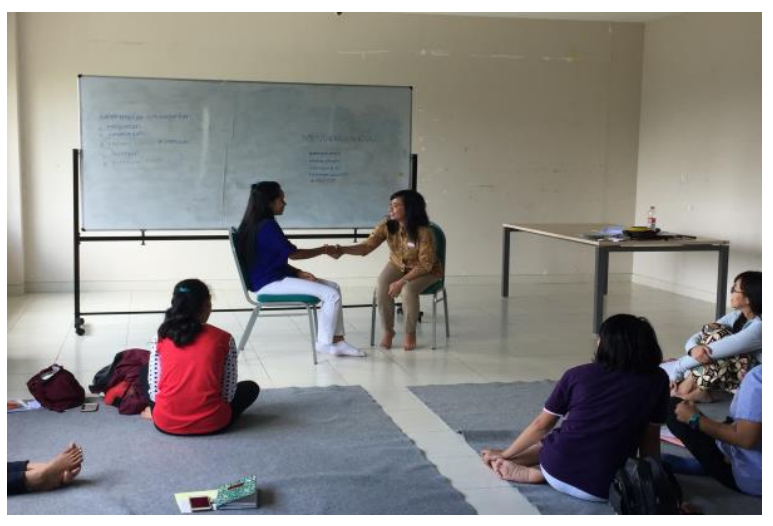

Gambar 2. Simulasi Mendengar Aktif yang Baik dan Buruk 


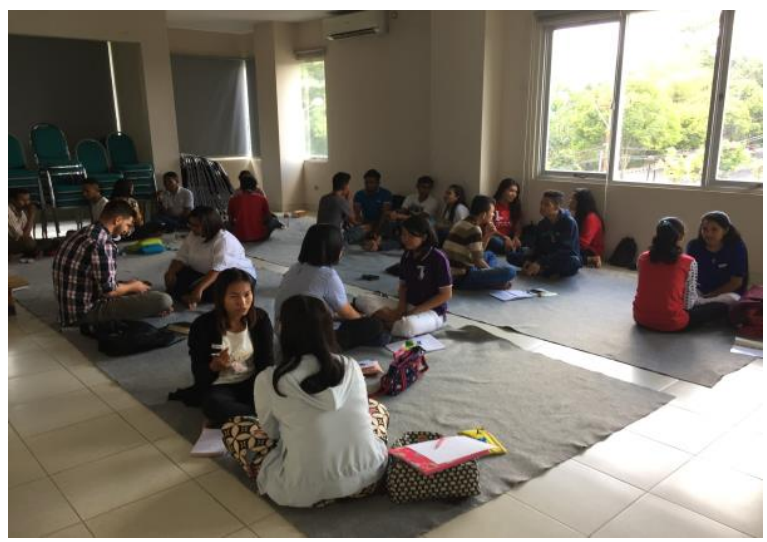

Gambar 3. Simulasi Mendengar Aktif (Berpasangan)

Pada sesi ketiga, peserta diajak untuk mengeksplorasi berbagai kegiatan yang dapat dilakukan untuk membantu para korban yang menampilkan gejala Posttraumatic Stress Disorder (PTSD). Kegiatan yang pertama kali diajarkan adalah kegiatan yang dapat membantu para korban mengekspresikan emosi mereka. Hal ini dilakukan mengingat salah satu gejala yang umum dialami oleh individu setelah mengalami kejadian traumatis adalah avoidance atau menghindari berbagai stimulus yang mengingatkan akan trauma (avoidance) (American Psychiatric Association, 2013). Salah satu hal yang termasuk avoidance adalah membicarakan hal tersebut dengan orang lain. Kegiatan yang diberikan berupa menggambar dan beberapa peserta yang bersedia menceritakan gambarnya kepada seluruh peserta. Selain itu teknik ekspresi emosi lain yang diajarkan adalah bercerita dengan menggunakan bantuan boneka jari. Pada kegiatan ini para peserta secara berkelompok diminta untuk bermain peran dan bercerita dengan topik bebas. Di dalam kelompok, para peserta juga dapat saling bertanya satu dengan yang lain. Gejala lain yang muncul saat individu mengalami trauma adalah perubahan dalam reaktivitas (hypervigilant, mudah cemas, mudah kaget, sulit tidur, sulit berkonsentrasi, agresif) (American Psychiatric Association, 2013). Oleh karena itu diberikan juga pelatihan untuk melakukan teknik relaksasi, berupa latihan pernapasan, Butterfly Hug, dan meniup busa sabun. Kegiatan yang dipilih adalah kegiatan yang menyenangkan dan tidak memerlukan banyak peralatan mengingat kondisi para korban yang kebanyakan masih berada di tenda pengungsian. Peserta diberikan informasi mengenai tahapan teknik relaksasi, diberikan kesempatan untuk mencoba teknik tersebut pada diri sendiri, dan diakhiri dengan diskusi mengenai hal yang dirasakan setelah mencobakan teknik tersebut.

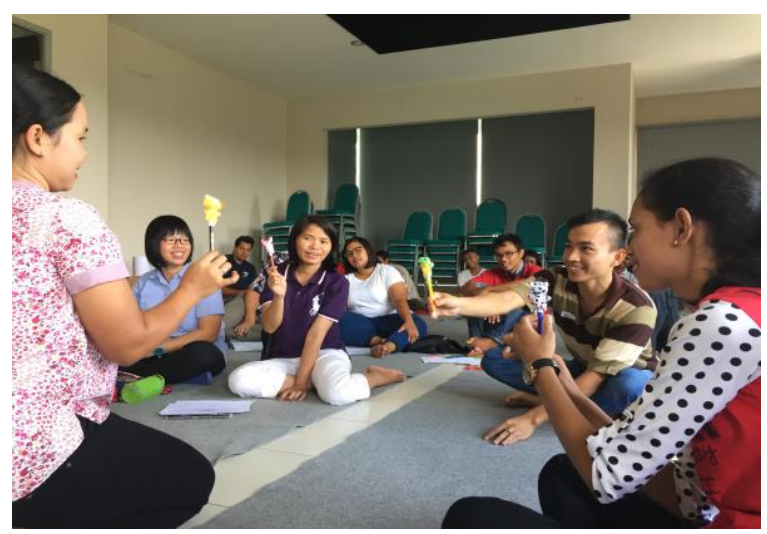

Gambar 4. Simulasi Teknik Ekspresi Emosi dengan Boneka Jari (Berkelompok)

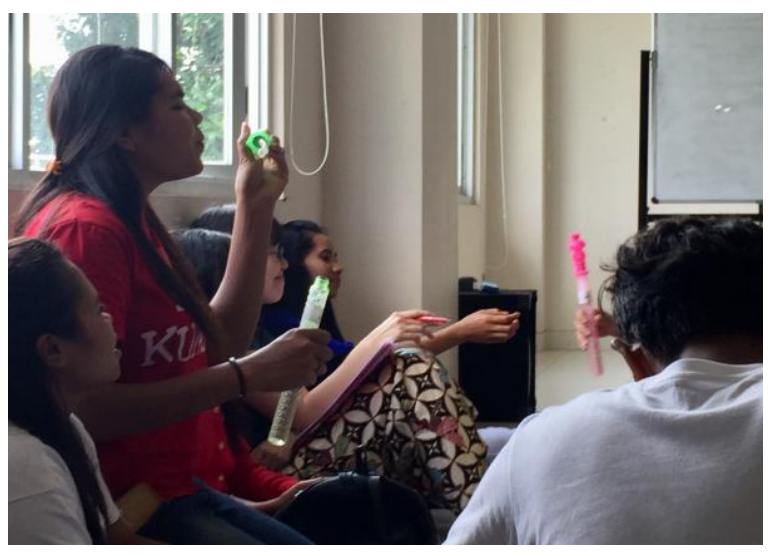

Gambar 5. Simulasi Teknik Relaksasi (Meniup busa sabun)

\section{Evaluasi Kegiatan}

Evaluasi kegiatan dilakukan di akhir kegiatan dengan memberikan pertanyaan terbuka mengenai lima hal, yaitu 1). Harapan yang

Lingkungan Hidup dan Bencana 
tercapai/tidak tercapai melalui keikutsertaan dalam kegiatan yang dilakukan, 2). Hal yang didapatkan selama kegiatan, 3). Rating/penilaian kegiatan dan hal yang sudah baik dilakukan dalam kegiatan ini, 4). Hal yang masih kurang atau perlu dikembangkan dalam kegiatan ini, 5). Hal yang akan dilakukan peserta setelah mengikuti kegiatan ini,

Hasil evaluasi dianalisa secara kualitatif dengan menyimpulkan tema-tema yang muncul berdasarkan jawaban peserta. 19 peserta (83\%) menyatakan harapannya dalam mengikuti kegiatan ini sudah tercapai, sedangkan sisanya tidak menjawab pertanyaan. Melalui kegiatan ini, terdapat beberapa hal yang didapatkan oleh peserta, yaitu adanya pengetahuan baru mengenai trauma dan penanganannya, mengetahui cara merespon korban melalui teknik mendengarkan, mengetahui langkahlangkah yang bisa dilakukan untuk menolong korban melalui kegiatan bermain yang sederhana, mengetahui bagaimana melakukan teknik relaksasi sebagai salah satu cara menolong korban. Namun ternyata hal yang didapatkan tidak hanya terkait dengan pengetahuan. Beberapa peserta mendapatkan pembelajaran bagi dirinya sendiri terkait dengan perannya sebagai relawan, misalnya mereka menjadi lebih mudah memahami korban, kegiatan ini membuatnya dapat menguatkan diri sendiri untuk menolong orang lain, adanya pemahaman bahwa mereka perlu menolong diri sendiri terlebih dahulu sebelum menolong orang lain, serta menjadi lebih bersemangat dalam beraktivitas.

Hal yang didapatkan peserta dalam kegiatan ini juga didukung dengan evaluasi mereka mengenai kegiatan ini. Dari 23 peserta yang mengikuti kegiatan, 17 orang (74\%) menuliskan rating evaluasi mereka dengan angka. Rata-rata angka yang didapatkan oleh kegiatan ini adalah 8.3, sehingga dapat disimpulkan kegiatan ini dianggap cukup baik bagi peserta. Hal-hal yang dianggap sudah baik dalam kegiatan ini berupa penyampaian materi yang sederhana dan mudah dimengerti, informasi yang cukup detil dan sesuai kebutuhan, teknik-teknik yang praktis dan mudah ditemukan peralatannya, serta interaksi yang baik antara pembawa materi dan peserta.

Peserta juga memberikan beberapa saran perbaikan terkait dengan materi edukasi yang diberikan serta hal teknis mengenai pengaturan kegiatan. Dalam kegiatan untuk para relawan di lapangan, akan lebih baik jika materi yang diberikan dikontekstualisasikan dengan keadaan di Lombok. Selain itu diperlukan juga adanya simulasi atau latihan yang lebih banyak mengenai teknik-teknik yang diajarkan. Selain itu, adanya kebutuhan informasi tambahan mengenai penanganan individu yang sudah mengalami trauma berkepanjangan. Sedangkan hal yang perlu diperbaiki terkait dengan hal teknis pengaturan kegiatan adalah waktu pelaksanaan kegiatan. Untuk kegiatan yang mengajarkan beberapa teknik dan simulasi, sebaiknya kegiatan dapat dilakukan dalam waktu lebih dari satu hari. Waktu yang terbatas mengakibatkan pembicara menyampaikan materi dengan lebih cepat. Selain itu diperlukan waktu istirahat yang lebih banyak mengingat kegiatan ini cukup padat dan hanya dilakukan dalam satu hari.

Setelah mengikuti kegiatan ini, secara umum para peserta menyatakan akan membagikan materi atau pengetahuan yang sudah mereka dapatkan bagi orang lain, mulai mengaplikasikan teknik yang sudah diajarkan kepada komunitas yang akan mereka temui nantinya, mengadaptasi dan mengembangkan teknik-teknik yang sudah didapatkan sesuai dengan konteks korban gempa bumi di Lombok.

Follow up kegiatan Trauma Healing ini telah dilakukan oleh Direktur BGRI saat mengunjungi beberapa sekolah yang dilayani oleh peserta yang mendapatkan pelatihan. Follow up yang bersifat verbal ini menunjukkan adanya respon positif dari pihak sekolah Dari hasil follow up juga ditemukan adanya harapan untuk melatih kemampuan konseling bagi para guru untuk membantu mereka melakukan konseling kepada murid yang menjadi korban (Komunikasi Personal, Februari 2019).

Dari pemateri sendiri, terdapat beberapa hal yang perlu diperhatikan karena menjadi kekurangan dalam kegiatan ini. Pertama adalah waktu yang terbatas sehingga membuat diskusi dan simulasi tidak dapat dilakukan dalam waktu yang lama. Ini juga menyebabkan pendeknya waktu istirahat bagi peserta. Akan lebih baik untuk ke depannya, kegiatan Trauma Healing dapat dilakukan selama beberapa hari. Hal ini guna memfasilitasi diskusi lebih panjang yang bisa dilakukan oleh peserta, serta dan memperbanyak simulasi yang bisa dilakukan oleh peserta sebagai cara untuk melatih sebuah keterampilan. Yang kedua adalah tidak

$$
\text { Lingkungan Hidup dan Bencana }
$$


adanya kuesioner atau survey terkait dengan kondisi trauma peserta sebelum dan sesudah melaksanakan kegiatan. Kondisi ini membuat sulitnya melihat efektivitas kegiatan Trauma Healing bagi kondisi trauma peserta. Sedangkan saat menjawab evaluasi dengan pertanyaan terbuka, beberapa peserta tampak tidak memahami maksud pertanyaan dan menjawab hal yang tidak sesuai dengan kenyataan. Perlunya ada kuesioner mengenai kondisi trauma juga disebabkan karena peserta yang ikut kegiatan ini nantinya akan menjadi pihak yang turun ke lapangan. Akan lebih baik jika mereka sudah siap terlebih dahulu dan tidak memiliki kondisi trauma yang berat sebelum menemui masyarakat. Ini hanya dapat diketahui dengan pemberian alat ukur yang tepat.

\section{KESIMPULAN}

Kegiatan Trauma Healing ini dianggap sebagai kegiatan yang baik dan membantu para peserta dalam memahami secara lebih mendalam mengenai trauma, Psychological First Aid (PFA), teknik mendengar aktif, serta berbagai kegiatan untuk mengekspresikan emosi dan relaksasi yang dapat dilakukan sebagai langkah pendampingan para korban bencana gempa di Lombok.

Perbaikan lebih lanjut yang bisa dilakukan terkait dengan pengaturan waktu kegiatan yang lebih panjang, serta perlunya penggunaan alat ukur/survey sebagai tambahan evaluasi kegiatan yang secara khusus dapat mengukur kondisi trauma pada para peserta yang akan turun ke lapangan.

\section{UCAPAN TERIMAKASIH}

Ucapan terima kasih hendak disampaikan kepada Universitas Pelita Harapan, para pimpinan Fakultas Psikologi Universitas Pelita Harapan, pihak Lembaga Penelitian dan Pengabdian kepada Masyarakat (LPPM) Universitas Pelita Harapan, pihak Baptist Global Response International (BGRI), Jessica Ariela, serta pihak-pihak lain yang telah membantu pelaksanaan kegiatan ini.

\section{REFERENSI}

American Psychiatric Association. (2013).
Diagnostic and statistical manual of mental disorder ( $5^{\text {th }}$ Ed.). Washington, DC: American Psychiatric Association.

American Psychological Association (APA). (2013). Recovering emotionally from disaster. Ditemu kembali dari https://www.apa.org/helpcenter/recovering-disasters pada 7 Oktober 2018

American Psychological Association (APA). (2019). Trauma. Ditemu kembali dari https://www.apa.org/topics/trauma/ pada 5 Oktober 2018

Badan Meteorologi, Klimatologi, dan Geofisika (BMKG). (2018). Ulasan Guncangan Tanah Akibat Gempa Lombok Timur 29 Juli 2018. Ditemu kembali dari https://www.bmkg.go.id/seismologi-teknik/ulasanguncangan-tanah.bmkg? $\mathrm{p}=$ ulasan-guncangan-tanahakibat-gempa-lombok-timur-29-juli-

2018\&tag=ulasan-guncangan-tanah\&lang=ID pada 7 Oktober 2018

Badan Nasional Penanggulangan Bencana (BNPB). (2018). Dampak Gempa Lombok: 436 Orang Meninggal dan Kerugian Ekonomi Lebih dari 5.04 Trilyun Rupiah. Ditemu kembali dari https://bnpb.go.id/dampak-gempa-lombok-436orang pada tanggal 20 Agustus 2018.

Badan Nasional Penanggulangan Bencana (BNPB). (2018). Update Gempa Bumi Lombok. Ditemu kembali dari https://www.bnpb.go.id/indonesia-gempabumilombok pada 7 Oktober 2018

Baptist Global Response International. (2018). About. Ditemu kembali dari http://bgri.org/about/ pada tanggal 20 Agustus 2018.

British Broadcasting Corporation (BBC). (2018). Gempa Lombok: Setidaknya 16 orang meninggal dunia, 5.000 lebih masih di penampungan. Ditemu kembali dari https://www.bbc.com/indonesia/indonesia44996132 pada 7 Oktober 2018.

$$
\text { Lingkungan Hidup dan Bencana }
$$


Lestari, D. (2018). Data Terbaru Korban

Jiwa Gempa Lombok Mencapai 564 Orang. Ditemu kembali dari

https://www.viva.co.id/berita/nasional/1080428data-terbaru-korban-jiwa-gempa-lombok-mencapai564-orang pada 7 Oktober 2018

Wirahadi, U. \& Wahyuningsih, D. (2018). Hari-hari penuh trauma para korban gempa Lombok (1). Ditemu kembali dari https://www.jawapos.com/features/22/08/2018/harihari-penuh-trauma-para-korban-gempa-lombok-1/ pada 7 Oktober 2018
World Health Organization (WHO). (2016). Psychological first aid for all. Ditemu kembali dari https://www.who.int/mental_health/world-mentalhealth-day/ppt.pdf pada 10 Oktober 2018

Wright, H. N. (2011). The complete guide to crisis \& trauma counseling: What to do and say when it matters most! Bloomington, MN: Bethany House Publishers. 